\title{
PROBLEMATIKA MADRASAH DINIYAH (MD) DI KOTA PALOPO SULAWESI SELATAN PASCA OTONOMI DAERAH
}

\author{
Muhaemin \\ Dosen Sekolab Tinggi Agama Islam Negeri (STAIN) Palopo \\ eimahady79@yaboo.com
}

\begin{abstract}
This research aims to map the opportunities of the Madrasab Diniyah in Palopo City, specially for institutional development context and analyzing the challenges faced in realizing the ideal Madrasab Diniyah after regional autonomy. This research is a qualitative descriptive. Ources of data are obtained from interviews, observation and documentation. Madrasab Diniyah development opportunities in Palopo supported by the Center Education Qur'an that can be developed into a better madrasab diniyah. Other opportunities dimension is the establishment of religion by the government of Palopo as the direction of development in Palopo. Challenges faced: first, the means and inadequate infrastructures. Secondly, there is no central figure. Third, public support is not maximized. Fourth, there has been no serious attention from the goverment. Fifth: the people have felt confortable with the Center of Qur'an Education.
\end{abstract}

Keywords: Opportunities, Challenges, Madrasab Diniyah

\begin{abstract}
Abstrak
Penelitian ini bertujuan untuk memetakan peluang yang dimiliki madrasah diniyah di Kota Palopo, kbususnya dalam konteks pengembangan kelembagaan dan menganalisis tantangan yang dibadapi dalam mewujudkan madrasah diniyah yang ideal pasca otonomi daerah. Jenis penelitian ini adalah kualitatif deskriptif. Sumber data diperoleh dari wawancara, observasi dan dokumentasi. Peluang pengembangan lembaga madrasab diniyah didukung oleh adanya sejumlah Taman Pendidikan al-Qur'an (TPA) yang dapat dikembangkan menjadi madrasab diniyab yang lebib baik. Selain itu, penetapan dimensi religi sebagai salabsatu arah pembangunan Kota Palopo. Tantangan yang dibadapi, pertama: sarana dan prasarana tidak memakai. Kedua, tidak ada tokoh penggerak. Ketiga, dukungan masyarakat tidak signifikan. Keempat: tidak
\end{abstract}


perhatian serius dari Pemerintah Kota. Kelima, masyarakat merasa cukup dengan adanya TPA (Taman Pendidikan al-Qur'an)

Kata kunci: Opportunities, Challenges, Madrasah Diniyah

\section{Pendahuluan}

Menarik untuk melihat kembali posisi pendidikan Islam dan memotret perkembangan lembaga pendidikan Islam termasuk di dalamnya Madrasah Diniyah (MD) pasca reformasi. Sedikitnya ada dua alasan untuk fokus terhadap eksistensi pendidikan Islam pasca reformasi. Pertama, Undang-Undang Nomor 20 tahun 2003 tentang Sistem pendidikan Nasional memberikan ruang yang cukup luas bagi pengembangan institusi pendidikan agama, khususnya Pendidikan Islam. Kedua, kondisi lembaga pendidikan Islam di Indonesia yang sebagian besar masih bersifat tradisional dan hanya dipandang sebagai pendidikan kelas dua, menyebabkan lembaga pendidikan Islam kalah bersaing dengan lembaga pendidikan lainnya (Usman, 2005: 1).

Menurut Azyumardi Azra, selama kurun waktu lebih dari beberapa dasawarsa sejak Indonesia bebas dari kolonialisme, dunia pendidikan Islam di Indonesia dikatakan belum memberikan kontribusi yang signifikan terhadap kemajuan bangsa. Pendidikan Islam saat ini kelihatan sering terlambat merumuskan diri untuk merespon perubahan dan kecenderungan perkembangan masyarakat sekarang dan masa mendatang (Azra, 2005: xi).

Kritik membangun yang disampaikan oleh pengamat pendidikan di atas, harus dijadikan cambuk oleh pengelola dan praktisi pendidikan Islam untuk melakukan evaluasi sekaligus menata lembaga pendidikan Islam ke arah yang lebih baik seiring dengan lahirnya Undang-Undang Sistem Pendidikan Nasional Tahun 2003 dan PP 55 tahun 2007 tentang Pendidikan Agama dan Pendidikan Keagamaan yang memberikan peluang bagi pengembangan pendidikan Islam.

Undang-Undang Sistem Pendidikan Nasional nomor 20 tahun 2003 yang lahir setelah reformasi, telah membuka peluang yang lebih luas bagi pengembangan pendidikan Islam menjadi lebih 
maju. Banyak pihak merasa bahwa Undang-Undang Sisdiknas ini secara konseptual merupakan titik balik pencerahan dalam mengembangkan, memberdayakan serta meningkatkan sistem pendidikan Islam di Indonesia. Undang-Undang tersebut dalam konteks peningkatan kualitas menjadi sangat relevan. Harapan bagi pengembangan pendidikan Islam di Indonesia, seolah menemukan energi baru.

Seperti dipahami bahwa di dalam Undang-Undang SISDIKNAS telah memberikan perspektif baru yang revolusioner bagi perbaikan sektor pendidikan, dimana pendidikan telah menjadi urusan publik secara umum dengan mengurangi otoritas pemerintah, baik bertalian dengan kebijakan kurikulum, manajemen dan berbagai kebijakan pengembangan institusi pendidikan itu sendiri. Undangundang SISDIKNAS dipandang sebagai salah satu bentuk reformasi di bidang pendidikan.

Lahirnya Peraturan Pemerintah (PP) nomor 55 tahun 2007 tentang Pendidikan Agama dan Pendidikan Keagamaan sebagai amanat Undang-Undang Nomor 20 tentang Sistem Pendidikan Nasional (khususnya Pasal 12 ayat (4), Pasal 30 ayat (5), dan Pasal 37 ayat (3)) merupakan babak baru dalam melihat posisi Pendidikan Diniyah. Dalam PP ini, posisi Pendidikan Diniyah disebutkan sebagai lembaga pendidikan keagamaan Islam yang setara dengan lembaga pendidikan lainnya dalam konteks pencapaian tujuan pendidikan nasional.

Eksistensi Pendidikan Diniyah dan Pesantren di negeri ini menghadapi beberapa tantangan dan peluang seiring dinamika kebijakan pendidikan yang berlaku di negeri. Dimulai dari UndangUndang No. 4 Tahun 1950 tentang Dasar-Dasar Pendidikan dan Pengajaran di Sekolah, UU No.12 Tahun 1954 tentang pernyataan berlakunya Undang-Undang Nomor 4 Tahun 1950, Undang-undang Nomor 19 Tahun 1965 tentang Pokok-Pokok Sistem Pendidikan Nasional, Undang-Undang Nomor 2 Tahun 1989 tentang Sistem Pendidikan Nasional, dan pasca reformasi Undang-Undang Nomor 20 Tahun 2003 tentang sistem pendidikan nasional yang ditindaklanjuti dengan PP Nomor 55 tahun 2007 (Daulay, 2004: vi). 
Dalam perkembangan selanjutnya, beberapa ormas Islam yang menyelenggarakan pendidikan diniyah mulai melakukan inovasi termasuk dalam dalam hal kurikulum. Sehubungan dengan perkembangan itu, dalam rangka pembinaan dan bimbingan Departemen Agama mengeluarkan Peraturan Menteri Agama Nomor 13 Tahun 1964 yang antara lain dijelaskan:

1. Madrasah diniyah ialah lembaga pendidikan yang memberikan pendidikan dan pengajaran secara klasikal dalam pengetahuan agama Islam kepada siswa sedikitnya 10 orang lebih, dengan usia 7-18 tahun.

2. Pendidikan dan pengajaran Madrasah Diniyah untuk memberi tambahan pengetahuan agama kepada pelajar-pelajar yang merasa kurang menerima pelajaran agama di sekolah umum.

3. Madrasah Diniyah ada tiga tingkatan yaitu ula, wustha, dan ulya

Pasca reformasi, pendidikan diniyah mendapatkan tempat dalam Sisdiknas. Salah satu poin penting dalam PP 55 adalah pengakuan penyelenggaraan pendidikan keagamaan pada berbagai jalur, yaitu jalur formal, nonformal dan informal. Khusus pendidikan diniyah, bentuk penyelenggaraannya sebagai berikut:

1. Pendidikan Diniyah Formal

Pendidikan diniyah formal menyelenggarakan pendidikan ilmuilmu yang bersumber dari ajaran agama Islam pada jenjang pendidikan anak usia dini, pendidikan dasar, pendidikan menengah, dan pendidikan tinggi (Pasal 15 PP No. 55 Tahun 2007)

2. Pendidikan Diniyah Nonformal

Pendidikan diniyah nonformal diselenggarakan dalam bentuk pengajian kitab, Majelis Taklim, Pendidikan Al Qur'an, Diniyah Takmiliyah, atau bentuk lain yang sejenis (Pasal 21 PP No. 55 Tahun 2007)

3. Pendidikan Diniyah Informal

Pendidikan diniyah informal diselenggarakan di rumah oleh keluarga

Berdasarkan model di atas, maka dapat diasumsikan bahwa PP 55 tahun 2007 sangat memperhatikan keragaman model pen- 
didikan keagamaan yang telah berkembang di negeri ini. Sebagaimana telah diuraikan sebelumnya bahwa legitimasi penyelenggaraan Pendidikan keagamaan jalur formal, nonformal, dan informal sangat diperlukan untuk menjamin terjaganya heterogenitas model dan kemandirian yang menjadi ciri khas lembaga-lembaga pendidikan keagamaan.

Namun kenyataan menunjukkan bahwa Madrasah di Indonesia menampilkan tiga model yang masyhur. Pertama, Madrasah Diniyah; kedua, Madrasah Pondok Pesantren, dan ketiga, Madrasah yang diselenggarakan berdasarkan Surat Keputusan Tiga Menteri (Menteri Agama, Dalam Negeri, dan Menteri Pendidikan dan Kebudayaan) Tahun 1975 tentang Upaya Peningkatan Mutu Madrasah. Dampaknya, madrasah model ketiga inilah yang mendapat "fasilitas lebih" baik dari aspek ketenagaan, pendanaan, maupun sarana prasarana dibandingkan dengan madrasah model pertama dan kedua. Sehingga banyak madrasah diniyah yang dalam perjalanan tidak berkembang atau malah gulung tikar akibat pemberian "fasilitas" dari pemerintah yang sangat jauh dari kebutuhan operasionalnya. Alasan klasiknya karena madrasah diniyah termasuk lembaga pendidikan nonformal (supplement).

Berdasarkan pasal 12 dan penjelasannya di atas, maka seharusnya tidak terjadi lagi diskriminasi terhadap pendidikan diniyah dan pesantren. Bahkan dalam konteks otonomi daerah sekarang ini, berdasarkan amanat PP 55, maka pemerintah daerah berkewajiban memberikan dukungan moril dan materil bagi pelaksanaan pendidikan diniyah dan pesantren. Hal ini harus ditegaskan karena pendidikan diniyah dan pesantren memiliki andil besar dalam menuntaskan berbagai program pemerintah termasuk wajib belajar.

Salah satu kendala utama di masyarakat yang terkait dengan eksistensi lembaga pendidikan diniyah adalah kendala kultural; masyarakat cenderung melihat lembaga-lembaga pendidikan diniyah sebagai lembaga pendidikan kelas dua, sulit bersaing dengan lembaga pendidikan lainnya. Terlebih lagi di era otonomi daerah, berbagai lembaga pendidikan yang dikelola di bawah pemerintah daerah memperoleh dukungan dana dan fasilitas yang maksimal.

Dalam konteks Kota Palopo, berdasarkan data Direktorat Jendral Pendidikan Islam melalui Direktori Madrasah Diniyah, tercatat 
sedikitnya 49 Madrasah Diniyah di Kota Palopo. Madrasah Diniyah tersebut terdapat di wilayah kecamatan Wara (19 MD), Wara Utara (18), Wara Selatan (4 MD), Telluwanua (3 MD), Wara Timur (2 MD) dan Mungkajang (4 MD).

Penelitian ini bermaksut memetakan corak Madrasah Diniyah tersebut dan mencermati dinamika kelembagaan yang dialaminya khususnya pasca otonomi daerah dan berlakunya PP 55 tahun 2007 tentang Pendidikan Agama dan Keagamaan.

Berdasarkan latar belakang masalah, dirumuskan permasalahan sebagai berikut: bagaimana peluang Madrasah Diniyah pasca otonomi daerah di Kota Palopo? tantangan apa saja yang dihadapi Madrasah Diniyah di Kota Palopo dalam konteks pengembangan kelembagaan?

\section{Teori Petumbuhan dan Perkembangan Madrasah}

Realitas menunjukkan bahwa ada kemiripan Madrasah Diniyah dengan pondok pesantren. Alasan yang mendasari adalah bahwa akar kultural Madrasah Diniyah secara eksistensial tidak bisa dilepaskan dari pesantren karena komunitas pendidik yang mengelola Madrasah Diniyah itu sendiri adalah mayoritas santri-santri lulusan pesantren yang mempraktekkan apa yang mereka peroleh dan pelajari dari model pendidikan Pondok Pesantren. Namun, setiap Madrasah Diniyah memiliki ciri khas masing-masing, karena tergantung pada kreasi pengasuhya. Ada Madrasah Diniyah yang mengkhususkan pengajaran agama Islam saja, ada pula yang menambahkan dengan pengetahuan umum yang porsinya sekitar 30\% (Riyadi, 2006: 75).

Madrasah Diniyah (Madin) adalah model lembaga pendidikan Islam yang mengajarkan 100\% ilmu-ilmu agama. Jenjang madrasah ini meliputi tiga jenjang yaitu awwaliyah (dasar), wustho (menengah), 'ulya (tinggi). Secara institusional, pendidikan Madrasah Diniyah di Indonesia sangat beragam, ada yang dikelola oleh organisasi kemasyarakatan (ormas), yayasan, dan ada juga yang dikelola oleh perorangan. Sedangkan secara fungsional, madrasah ini terbagi menjadi tiga sifat yaitu Madrasah Diniyah Komplement (Madrasah Diniyah Wajib/Komplemen, siswa sekolah formal wajib 
menjadi siswa madrasah diniyah), Samplement (Madrasah Diniyah Samplemen adalah madrasah diniyah murni atau independen, yaitu madrasah diniyah yang siswa hanya menempuh pendidikan di madrasah diniyah tersebut dan tidak merangkap di sekolah umum atau madrasah formal) dan Supplement.

Secara historis agak sulit melacak kapan mulai berdirinya Madrasah Diniyah sebagai sebuah institusi pendidikan Indonesia. Kesulitan ini disebabkan karena langkanya referensi yang menjelaskan eksistensi Madrasah Diniyah dalam konstelasi perkembangan Institusi pendidikan Islam. Tetapi kemunculan Madrasah Diniyah sebagai Institusi pendidikan Islam merupakan perpanjangan tangan dari Pondok Pesantren (Islamic boarding school) dengan model kelembagaan dan kurikulum yang sedikit berbeda. Pondok pesantren didirikan oleh kyai dan keluarganya yang concern dengan pemberdayaan umat, sedangkan Madrasah Diniyah secara umum didirikan karena inisiatif dan kerja kolektif beberapa orang yang memiliki concern dan tujuan yang sama yaitu untuk menyelenggarakan pendidikan Islam bagi masyarakat sekitarnya (Madrasah Diniyah Pelengkap/suplemen, adalah madarasah yang sifatnya hanya untuk menambah pengetahuan agama siswa).

Dalam kajian historis pendidikan Islam di Indonesia, pada umumnya para peneliti menulis bahwa awal berdirinya Madrasah Diniyah di Indonesia adalah pada zaman penjajahan Belanda. Madrasah Diniyah Mambaul Ulum Surakarta yang didirikan oleh R. Hadipati Sosrodiningrat dan R.Tafsirul Anam pada tahun 1905 merupakan Madrasah Diniyah pertama di Jawa, Madrasah Adabiyah (Adabiyah School) Padang Panjang yang didirikan oleh Abdullah Ahmad pada tahun 1907, Madrasah Diniyah (Diniyab School) Minangkabau yang didirikan oleh Zainuddin Labai al-Yunusiy pada tahun 1915 merupakan Madrasah Diniyah pertama di Sumatera. Madrasah-madrasah tersebut, penguatan kurikulumnya lebih berorientasi pada pengajaran ilmu-ilmu keagamaan disamping memberikan pengajaran ilmu-ilmu umum yaitu baca tulis latin dan berhitung (Maksum, 1999: 76). Kemudian disusul pendirian berbagai Madrasah Diniyah Muhammadiyah Yogyakarta, Madrasah al-Arabiyah al-Islamiyah (MAI) di Sengkang Sulawesi Selatan dan lain-lain. 
Dalam konteks perkembangan madrasah diniyah saat ini, penelitian Agus Maimun dari UIN Malang menyimpulkan, Madrasah Diniyah Takmiliyah sebagai salah satu tingkatan madrasah diniyah perlu melakukan kajian ulang terhadap kurikulum yang ada, agar kurikulum lebih fungsional bagi kehidupan keagamaan siswa dalam menghadapi realita sosial. (Maimun: 2006)

Berdasarkan paparan di atas, untuk pengembangan ke depan, maka madrasah diniyah dapat berisfat komplement, samplement dan supplement.

\section{Teori Corak Pendidikan}

Pendidikan adalah kegiatan yang bersifat sosial kemasyarakatan. Keadaannya selalu berbeda-beda sesuai dengan perbedaan corak, sifat dan kebudayaan yang berkembang di masyarakat tersebut. (al-Ainain, 1980: 37). Teori ini berlaku terhadap dinamika madrasah diniyah. Eksistensi pendidikan keagamaan Islam di Indonesia termasuk didalamnya pendidikan Diniyah dan Pesantren selalu dihadapkan kepada berbagai tantangan dan dinamika.

Qurais Shihab berpendapat bahwa sistem serta tujuan pendidikan bagi suatu masyarakat atau negara tidak dapat di impor atau di ekspor dari atau ke suatu negara atau masyarakat. Ia harus timbul dalam masyarakat itu sendiri. Ia adalah pakaian yang harus diukur dan dijahit sesuai dengan bentuk dan ukuran pemakainya berdasarkan identitas, pandangan hidup serta nilai-nilai yang terdapat dalam masyarakat atau negara tersebut. (Shihab, 1992: 175).

Berdasarkan perspektif teoritis dan historis di atas, eksistensi Pendidikan Diniyah dan Pesantren di negeri ini menghadapi beberapa tantangan dan peluang seiring dinamika kebijakan pendidikan yang berlaku di negeri ini. Dalam konteks otonomi daerah, kebijakan pengembangan madrasah diniyah tidak dapat dipisahkan dari kebijakan pemerintah pusat (Kementerian Agama) sebagai pemegang regulator pendidikan agama dan keagamaan serta pemerintah daerah sebagai penanggungjawab pendidikan dasar dan menengah.

Hasil penelitian Rosdiana dari Balitbang Agama Makassar menunjukkan, Kementerian Agama sebagai pembina madrasah diniyah perlu meningkatkan pembinaan dan pelayanan kepada 
madrasah diniyah sehingga dapat berkiprah lebih optimal dalam peningkatan pengetahuan, perilaku, dan wawasan keagamaan siswa terutama siswa muslim di sekolah umum. Pengorganisasian pembinaan yang ada selama ini kurang menyentuh substansi madrasah diniyah. Penyuluh yang diharapkan melakukan pembinaan kurang optimal karena mereka lebih fokus pada majelis taklim, TPA, dan lain-lain. Kemudian pengawas madrasah juga tidak melakukan pembinaan secara khusus terhadap madrasah diniyah. Karena itu, perlu ditinjau ulang pola pembinaan madin oleh Kementerian Agama. (Rosdiana: 2001, 11)

Beberapa riset lainnya tentang pentingnya madrasah diniyah antara lain: Pertama, penelitian Anis Masykhur, tentang Pencarian identitas pendidikan diniyah di Indonesia (studi kasus penyelenggaraan pendidikan diniyah di Kaltim dan Kalsel). Penelitian menyimpulkan bahwa pengelola madrasah diniyah harus lebih kreatif agar dapat menarik calon siswa. Kedua, Haidar Putra Daulay, dalam buku Pendidikan Islam dalam Sistem Pendidikan Nasional di Indonesia, Jakarta: Prenada Media, 2004.

\section{Metode Penelitian}

\section{Desain Penelitian}

Pada prinsipnya, penelitian ini bersifat kualitatif deskriftif, yaitu peneliti bermaksud menjajaki, menguraikan, menerangkan dan memetakan corak dan posisi madrasah diniyah di Kota Palopo. Oleh karena itu pendekatan yang digunakan adalah pendekatan kualitatif.

\section{Teknik Pengumpulan Data.}

Untuk memperoleh data, dipergunakan cara berikut ini; observasi, wawancara dan penelusuran literatur kepustakaan

\section{Teknik Analisis Data}

Data-data yang telah diperoleh dan terkumpul, dilakukan kategorisasi kemudian dianalisis dengan menggunakan teknikteknik berikut: 
1. Data-data hasil interview diinventarisir untuk memperoleh perspektif yang jelas dari narasumber/responden.

2. Data kualitatif dianalisis dengan cara menganalisa statemen kunci, menganalisa dokumen-dokumen lembaga (madrasah diniyah) dan melakukan pemetaan dari tiap institusi.

\section{Deskripsi Data}

Posisi Madrasah di antara lembaga Pendidikan di Kota Palopo

Berdasarkan data dari pemkot Palopo, lembaga pendidikan yang ada di Kota Palopo antara lain:

\section{Tabel 1}

Fasilitas Pendidikan di Kota Palopo 2010

\begin{tabular}{clcc}
\hline No & \multicolumn{1}{c}{$\begin{array}{c}\text { Jenis Fasilitas dan } \\
\text { Pendidikan }\end{array}$} & $\begin{array}{c}\text { Jumlah } \\
\text { (Unit) }\end{array}$ & $\begin{array}{c}\text { Persentase } \\
\text { (\%) }\end{array}$ \\
\hline 1. & TK Negeri / Swasta & 38 & 21,23 \\
2. & SDN / Swasta/ MI & 75 & 41,90 \\
3. & SLTP/ Swasta/ MTs & 22 & 12,29 \\
4. & SLTA/ Swasta/ MA & 31 & 17,32 \\
5. & Perguruan Tinggi /Akedemi & 13 & 7,26 \\
\multicolumn{2}{c}{ JUMLAH } & 179 & 100,00 \\
\hline
\end{tabular}

Dalam konteks madrasah diniyah, menurut Arifin Difinubun, terdapat sejumlah pendidikan diniyah di Palopo yang umumnya adalah TPA, antara lain (Depag Palopo, 2010: 1):

1. Pesantren Putri Datuk Sulaiman

2. Masjid Jami' Palopo

3. Opu Daeng Risaju

4. TPA Malaja

5. MD al-Baraqah

6. Masjid al-Furqan

7. Nurul Ilmi SMP 3

8. MD Masjid Agung

9. MD Rahmat Ilahi

10. MD Al-Awwabin

11. MD Nurul Bahri Jl. Cakalang. 
Pada tahun 2008/2009 Jumlah Madrasah Diniyah adalah:

1. Ula : 31

2. Wustho : 7

3. Ulya : 2

Dengan jumlah santri

1. Ula Laki-laki : 1140 dan Perempuan : 1688

2. Wustha Laki-laki : 102 dan Perempuan : 521

3. Ulya Laki-laki : 103 dan Perempuan : 320.

Kualfikasi Guru

1. SMU 90 Orang

2. Diploma 25 Orang

3. S1 17 Orang

4. $\mathrm{S} 2$

Jumlah Tenaga Pengajar

1. Laki-Laki : 37 Orang

2. Perempuan : 95 Orang

Potret Madrasah Diniyah di Kota Palopo

Secara umum, kegiatan madrasah diniyah di Palopo bergabung dalam kegiatan TPA, baik yang dikelola organisasi maupun masjid. Potret umum madrasah diniyah tersebut dapat dilihat dalam profil singkat di bawah ini:

1. TPA Dharma Wanita Kementerian Agama

Nama TPA : TPA Dharma Wanita Kementerian Agama Palopo

Alamat : Jl. Peda-Peda Kota Palopo

Pimpinan : ST. Aminah

Kegiatan : Bimbingan mengaji, do'a-do'a shalat dan do'a harian.

2. MD al-Awwabin

Nama TPA : TPA al-Awwabin Muhammadiyah

Alamat : Jl. Datuk Sulaiman No. 51 Palopo

Pimpinan : Firman Patawari, S. Pd 
Kegiatan : Majlis Taklim, Bimbingan baca tulis al-Qur'an, bimbingan bacaan dan praktek shalat

3. MD Masjid Agung

Nama TPA : TPA Masjid Agung Palopo

Alamat : Jl. KH. Ramli

Pimpinan : ST. Munirah

Kegiatan : Pengenalan dasar-dasar al-Qur'an, mengajarkan doa harian, mengajarkan surah-surah pendek

4. TPA Masjid As-Syura

Nama TPA : TPA Masjid Assuyra

Alamat : Jl. Anggrek Palopo

Pimpinan : Drs. H. Zainuddin Samide, MA

Kegiatan : Mengajarkan baca tulis al-Qur'an, doa-doa pendek, surah-surah pendek

5. TPA Masjid RRS Balandai

Nama TPA : TPA Masjid RSS Balandai

Alamat : Balandai, Palopo

Pengurus : Muhadir Azis

Kegiatan : Bimbingan baca tulis al-Qur'an, doa harian, praktek shalat, surah-surah pendek

6. MD al-Barakah

Nama TPA : TPA al-Barakah Masjid Terminal Kota Palopo

Alamat : Jl. Kelapa, Palopo

Pengurus : Khusaeri

Kegiatan : Bimbingan baca tulis al-Qur'an, doa harian

7. TPA al-Jihad

Nama TPA : al-Jihad Palopo

Alamat : Jl. Dr. Ratulangi Palopo

Pengurus : Arifin D

Kegiatan : Pengajaran baca tulis al-Qur'an, pengajian agama, bimbingan ibadah

8. MD Al-Furqan

Nama TPA : al-Furqa

Alamat : Jl. KH. A. Dahlan, Palopo

Pengurus : Ruhanda Muhammad, S. Ag

Kegiatan : Pengajaran baca tulis al-Qur'an, bimbingan iba- 
dah, pengajian agama

9. MD PMDS Putra

Nama TPA : PMDS Putra

Alamat : Jl. Dr. Ratulangi Palopo

Pengurus : Drs. Mardi Takwim, M. HI

Kegiatan : Pengajian al-Quran, doa harian

10. MD PMDS Putri

Nama TPA : PMSD Putri

Alamat : Jl. Anggrek J/36

Pengurus : Mustaming, S. Ag, M. HI

Kegiatan : Pengajian baca tulis al-Qur'an, doa harian, bimbingan ibadah

\section{Analisis}

Hasil penelitian di lapangan menunjukkan bahwa belum terdapat madrasah diniyah dalam bentuk madrasah diniyah murni. Madrasah diniyah di Kota Palopo merupakan bagian tak terpisahkan dari program TPA. Problematika yang dialami tiap TPA berbeda-beda dalam mewujudkan madrasah diniyah yang ideal.

Secara umum, setidaknya sudah ada beberapa karakteristik pendidikan diniyah di bumi nusantara ini. Pertama, Pendidikan Diniyah Takmiliyah (suplemen) yang berada di tengah masyarakat dan tidak berada dalam lingkaran pengaruh pondok pesantren. Pendidikan diniyah jenis ini betul-betul merupakan kreasi dan swadaya masyarakat, yang diperuntukkan bagi anak-anak yang menginginkan pengetahuan agama di luar jalur sekolah formal. Kedua, pendidikan diniyah yang berada dalam lingkaran pondok pesantren tertentu, dan bahkan menjadi urat nadi kegiatan pondok pesantren. Ketiga, pendidikan keagamaan yang diselenggarakan sebagai pelengkap (komplemen) pada pendidikan formal di pagi hari. Keempat, pendidikan diniyah yang diselenggarakan di luar pondok pesantren tapi diselenggarakan secara formal di pagi hari, sebagaimana layaknya sekolah formal.

Memperhatikan beberapa karakteristik tersebut di atas, tampak bahwa penyelenggaraan pendidikan diniyah di beberapa daerah di nusantara ini mengalami krisis identitas, sebagaimana halnya 
yang terjadi di Kota Palopo.

Firman Patawari dari Madrasah Diniyah/TPA al-Awwabin Muhammadiyah, menyebutkan sejumlah poblematika yang dihadapi sehingga lembaganya tidak memiliki madrasah diniyah murni, antara lain:

1. Fasilitas tidak memadai

2. Anggaran tidak memadai

3. Kondisi sosial masyarakat yang tidak kondusif (Firman, 2011: 1).

ST Aminah dari TPA Dharma Wanita Kementerian Agama Palopo menegaskan keinginannnya untuk mengelola madrasah diniyah secara total. Namun hal tersebut menghadapi masalah dengan tidak tersedianya sarana dan prasarana (ST. Aminah, 2011: $1)$.

ST Munirah dari TPA Masjid Agung Palopo, menyatakan keinginan lembaganya membuka madrasah diniyah secara murni berdasarkan potensi yang dimiliki kota Palopo. Problematika yang dihadapi saat ini antara lain:

1. Sarana dan Prasarana

2. Ruang Belajar

3. Tenaga Pengajar (ST Munirah, 2011: 1)

Zainuddin Samide dari TPA As-syura menegaskan banyaknya tantangan yang dihadapi dalam pengembangan madrasah diniyah di Kota Palopo. Tantangan tersebut antara lain;

1. Kurang perhatian dari pemerintah dan Kementerian Agama

2. Dukungan masyarakat yang tidak maksimal

3. Sarana dan Prasarana

4. Tenaga pengajar.

Muhadir Aziz dari TPA RSS balandai menjelaskan bahwa masyarakat telah menganggap TPA sebagai manifestasi dari madrasah diniyah. Meski demikian, ia tetap berharap terwujudnya madrasah diniyah yang lengkap. Problematika yang dihadapi antara lain: 
1. Kurangnya dana

2. Dukungan masyarakat

3. Tidak adanya tokoh penggerak (Muhadir Aziz, 2011: 1)

Menurut khusaeri dari TPA al-Barakah Palopo, banyak problematika yang dihadapi dalam pendirian madrasah diniyah di kota palopo. Kendala tersebut antara lain:

1. Dukungan masyarakat yang kurang

2. Tidak ada tokoh penggerak

3. Kurangnya dukungan kebijakan dari Pemkot (Khusaeri, 2011: 1)

Arifin Difinubun dari TPA al-jihad Palopo menegaskan sejumlah problematika yang dihadapi dalam mewujudkan madrasah diniyah di kota Palopo. Kendal tersebut antara lain:

1. TPA dianggap cukup oleh masyarakat

2. Kurangnya tokoh agama

3. Kultur masyarakat yang tidak mendukung (Arifin Difinubun, 2011: 1)

Menurut Arifin Difinubun, tidak terdapat diniyah murni di Palopo, yang ada hanya diniyah complement. Diniyah complement artinya TPA yang diberikan mata pelajaran diniyah. Model seperti ini terdapat di Masjid Agung dan Masjid Jami Palopo.

Hal yang sama diakui oleh M. Arief selaku mantan Kakandepag Palopo, bahwa belum terdapat madrasah diniyah murni di Kota Palopo. Namun beberapa TPA dimasukkan dalam kategori Madrasah Diniyah berdasarkan data EMIS Departemen Agama pusat (Arief, 2011: 1).

Berdasarkan data di atas, problematika madrasah diniyah di Kota Palopo dapat digambarkan dalam tabel di bawah ini: 


\section{Tabel 2}

\section{Problematika Madrasah Diniyah}

\begin{tabular}{lcc}
\hline $\begin{array}{c}\text { Problematika Madrasah } \\
\text { Diniyah }\end{array}$ & $\begin{array}{c}\text { Volume yang } \\
\text { Menyatakan }\end{array}$ & Keterangan \\
\hline $\begin{array}{l}\text { Fasilitas Tidak Memadai } \\
\text { Anggaran Tidak }\end{array}$ & 4 \\
Memadai & 3 \\
$\begin{array}{l}\text { Kondisi Sosial } \\
\text { Masyarakat yang Tidak }\end{array}$ & 4 \\
$\begin{array}{l}\text { Kondusif } \\
\text { Tenaga Pengajar yang }\end{array}$ & 2 \\
$\begin{array}{l}\text { Kurang } \\
\text { Tidak Ada Tokoh }\end{array}$ & 3 \\
$\begin{array}{l}\text { Penggerak } \\
\text { Tidak Dukungan } \\
\text { Kebijakan Dari Pemkot } \\
\text { TPA Sudah Dianggap } \\
\text { Cukup Oleh Masyarakt }\end{array}$ & 3 \\
\hline
\end{tabular}

Menurut Anis Maskhur, berdasarkan hasil penelitiannya tentang madrasah diniyah di Kalimantan Selatan, terdapat setumpuk problem implementasi kurikulum di madrasah diniyah (Anis, 2009; 1). Tidak adanya dukungan yang simultan dan berkelanjutan dari instansi yang berwenang, maka penerapan-bahkan penyusunankurikulum di MD ini banyak bermunculan. Jika diidentifikasi, setidaknya ada beberapa hal;

Pertama, belum ada kurikulum yang tertulis. Mereka tidak mempunyai panduan dalam penerapan kurikulum tersebut. Namun tujuan utama dari penyelenggaraan madrasah diniyah ini adalah memberikan bekal kepada murid untuk bisa membaca Kitab Suci Al-Quran dengan baik dan benar.

Kedua, kurikulum dipahami hanya sebatas buku-buku yang dipergunakan dan dijadikan acuan belajar. Penjabaran-penjabaran semisal target pencapaian, standar kompetensi, atau pembagian tema-tema setiap pertemuan tidak menjadi hal yang penting.

Ketiga, pendekatan kurikulum yang dipergunakan adalah menamatkan buku secara berurutan dan berjenjang. Seorang ustadz akan mengganti buku pegangannya dengan kitab yang lebih tinggi 'status'nya jika telah menamatkannya. Mereka menyebutnya "untuk 
tabarukan" (mengambil berkah) dari buku yang dipelajarinya.

Keempat, ketidak tersedianya SDM yang tangguh. Para pengelola Madrasah Diniyah di Kalimantan terutama yang jauh dari pondok pesantren banyak dikelola oleh orang tua yang nota bene adalah pensiunan PNS yang dibantu oleh beberapa pemuda setempat yang menjadi asistennya dalam mengajar baca tulis huruf Al-Quran, atau alumni perguruan tinggi agama yang sedang mengalami masa transisi mencari pekerjaan. Sehingga untuk mengembangkan MD dan menyusun kurikulum, mereka tidak bisa diharapkan (Anis, 2009: 4)

Lebih lanjut, temuan Anis menunjukkan bahwa kurikulum madrasah diniyah pada umumnya belum tertulis. Hanya saja mereka dalam menentukan buku-bukunya dilakukan secara mandiri. Ada yang mengacu pada kurikulum yang pernah disusun oleh Departemen Agama. Adapula yang secara sporadis menentukan sendiri dengan mengukur kemampuan anak-anak didiknya. Jikalau diukur dengan tolok ukur pendidikan formal, jelas kurikulum pendidikan diniyah jenis ini masih jauh dari harapan.

Menurut Kaswad dari Bidang Pendidikan Keagamaan Departemen Agama Sulawesi Selatan, diharapkan lembaga pendidikan diniyah ke depan mampu melahirkan pendidikan bermutu yakni pendidikan yang dapat mengembangkan potensi peserta didik dengan tolak ukur pada enam pendekatan yaitu; (1) Secara akademik peserta didik dapt mengikuti proses pendidikannya ke tingkat yang lebih tinggi; (2) Secara moral, lulusan pendidikan tersebut dapat menunjukkan tanggungjawab dan kepeduliannya kepada masyarakat sekita; (3) Secara individual, lulusan pendidikan tersebut semakin meningkat keimanan dan ketaqwaanya, yaitu manusia yang melaksanakan perintah Allah sekaligus menjauhi segala larangan-Nya; (4) Secara sosial, lulusan pendidikan tersebut dapat berinterkasi dengan masyarakat sekitar; (5) Secara kultural, lulusan pendidikan tersebut dapt menginterpretasikan ajaran agamanya sesuai dengan lingkungan sosialnya; (6) secara ekonomi, lulusan pendidikan tersebut dapat memenuhi kebutuhan kehidupannya secara ekonomi dan mandiri (Kaswad, 2008: 9).

Pendidikan generasi muda dalam membentuk sumber daya manusia yang potensial merupakan kunci utama kemajuan suatu 
bangsa. Inti pendidikan itu sendiri pada dasarnya adalah proses alih informasi dan nilai nilai yang ada. Selama proses ini terjadi, pengalaman dan penalaran pengambilan keputusan seseorang akan bertambah baik. Hasil akhir suatu proses pendidikan adalah terbentuknya seseorang yang mampu berdiri sendiri, bekerja dan tak pernah berhenti untuk belajar serta mengembangkan apa yang telah diperolehnya.

Dari uraian para pakar di atas dapat dipahami bahwa pendidikan atau mendidik tidak hanya sebatas mentransfer ilmu saja, namun lebih jauh dan pengertian itu yang lebih utama adalah dapat mengubah atau membentuk karakter dan watak seseorang agar menjadi lebih baik, lebih sopan dalam tataran etika maupun estetika maupun perilaku dalam kehidupan sehari-hari.

Pendidikan merupakan bagian penting dari proses pembangunan yang ikut menentukan pertumbuhan ekonomi dan stabilitas suatu negara. Pendidikan juga merupakan investasi dalam pengembangan sumber daya manusia, dimana peningkatan kecakapan dan kemampuan diyakini sebagai faktor pendukung bagi manusia untuk mengarungi kehidupan. Dalam kerangka inilah pendidikan dipandang sebagai kebutuhan dasar bagi masyarakat Indonesia.

Dunia pendidikan merupakan penolong utama bagi manusia untuk menjalani kehidupannya, tanpa pendidikan, maka tidak akan ada perbedaan dengan keadaan pendahulunya pada masa purbakala. Asumsi ini melahirkan suatu teori, bahwa maju mundur atau baik buruknya suatu bangsa akan ditentukan oleh keadaan pendidikan yang dijalani bangsa itu (Nizar, 2001: 2).

Pendidikan harus mampu menyiapkan sumber daya manusia yang tidak sekedar penerima arus informasi global, tetapi harus memberikan bekal kepada mereka agar dapat mengolah, menyesuaikan, dan mengembangkan apa yang diterima melalui arus informasi itu, yaitu manusia yang kreatif dan produktif, sehingga pendidikan dalam hal ini harus ditempatkan pada visi sebagai agen pembangunan dan dan perkembangan yang tidak ketinggalan zaman. Manusia yang kreatif dan produktif ini yang harus dijadikan visi pendidikan, karena manusia yang demikianlah yang didambakan kehadirannya, baik secara individual, sosial, maupun nasional. 
Masyarakat akan sangat kecewa manakala dunia pendidikan justru menghasilkan manusia yang malas, kurang peka dan konsumtif (Nata, 2001: 83).

Pendidikan berfungsi untuk mempersiapkan anak didik menjadi manusia yang memiliki perilaku, nilai, dan norma sehingga mewujudkan totalitas manusia yang utuh dan mandiri sesuai sistim nilai yang berlaku. Namun selain itu, pendidikan harus juga secara mental mempersiapkan peserta didik dalam menghadapi hidup yang berubah-ubah. Jadi pendidikan bukan saja berperan memproduksi status quo, mempertahankan stabilitas dan kontinuitas, melainkan meningkatkan juga dorongan mencipta pada diri peserta didik dalam ikut menggalakkan dan memilih masa depan dengan kemungkinan yang baik untuk diaplikasikan, serta mampu mengurangi atau menghindari kemungkinan yang tidak baik (Linrung, 1995: 141).

Peranan pendidikan dalam pengembangan kualitas sumber daya insan secara mikro, yaitu sebagai proses belajar-mengajar: alih pengetahuan (transfer of knowledge), alih metode (transfer of methodologhy) dan alih nilai (transfer of value) (al-Munawwar, 2003:11).

Pendidikan lebih daripada sekedar pengajaran; yang terakhir ini dapat dikatakan sebagai suatu proses transfer ilmu belaka, bukan transformasi nilai dan pembentukan kepribadian dengan segala aspek yang dicakupnya. Dengan demikian, pengajaran lebih berorientasi pada pembentukan "tukang-tukang" atau para spesialis yang terkurung dalam ruang spesialisasinya yang sempit, karena itu, perhatian dan minatnya lebih bersifat teknis (Azra, 1991:3).

Jika sistem pendidikan Barat sekarang ini sering disebut-sebut mengalami krisis yang akut, itu tak lain karena proses yang terjadi dalam pendidikan tak lain daripada sekedar pengajaran. Pendidikan yang berlangsung dalam suatu schooling system tak lebih dari suatu transfer ilmu dan keahlian dalam kerangka tekno-struktur yang ada. Akibatnya, pendidikan-katakanlah pengajaran-menjadi suatu komoditi belaka dengan berbagai implikasinya terhadap kehidupan sosial kemasyarakatan (Azra, 1999: 4). 
Dalam konteks Indonesia, fungsi pendidikan sebagai sarana alih pengetahuan dapat ditinjau dari teori "human capital"; bahkan pendidikan tidak dipandang sebagai barang konsumsi belaka tetapi juga sebagai investasi. Hasil investasi ini berupa tenaga kerja yang mempunyai kemampuan untuk menerapkan pengetahuan dan keterampilannya dalam proses produksi dan pembangunan pada umumnya. Dalam kaitan ini proses alih pengetahuan dalam rangka pembinaan ilmu pengetahuan dan teknologi untuk berkembangnya manusia pembangunan. Dengan ilustrasi yang serupa, proses alih pengetahuan ini juga berperan pada proses pembudayaan dan pembinaan iman, takwa dan akhlak mulia (al-Munawwar, 2003: 14).

Sebagai sebuah karakteristik dalam sektor pendidikan, Undang-Undang Dasar Negara Republik Indonesia Tahun 1945 mengamanatkan pemerintah untuk mengusahakan dan menyelenggarakan satu sistem pendidikan nasional yang meningkatkan keimanan dan ketaqwaan kepada Tuban Yang Maha Esa serta akblak mulia dalam rangka mencerdaskan kehidupan bangsa. Karakter manusia Indonesia dalam undang-undang tersebut adalah manusia Indonesia yang berakhlak mulia, bertaqwa kepada Tuhan Yang Maha Esa, dan cerdas dalam kehidupannya.

Menjabarkan amanah tersebut, dalam UU Sisdiknas Tahun 2003 disebutkan bahwa "....Pendidikan adalah usaha sadar dan terencana untuk mewujudkan suasana belajar dan proses pembelajaran agar peserta didik secara aktif mengembangkan potensi dirinya untuk memiliki kekuatan spiritual keagamaan, pengendalian diri, kepribadian, kecerdasan, akhlak mulia, serta keterampilan yang diperlukan dirinya, masyarakat, bangsa dan negara" (UU Sisdiknas 2003). Hal ini mencerminkan sistem pendidikan yang dianut bangsa Indonesia.

Menurut analisis Abdurahman Mas'ud, tujuan seperti yang diamanatkan dalam Undang-Undang tersebut menempatkan moral keagamaan sebagai bagian yang penting darinya. Oleh karena itu aspek moral dan agama harus mendapatkan porsi yang signifikan dalam setiap kegiatan pendidikan (Mas'ud, 2004: 76).

Dari beberapa temuan realita di lapangan, setidaknya ada beberapa langkah taktis dan strategis yang perlu diperhatikan untuk semua pihak, yaitu: 
Pertama, penyelenggaraan dan pembekalan bagi guru-guru madrasah diniyah tentang materi metode dan strategi pembelajaran yang menarik dan disesuaikan dengan kompetensi daerahnya masing-masing adalah sebuah keharusan. Karena, sebagian besar pengelola madrasah diniyah mengeluhkan ketiadaan kreasi para pengajarnya dalam proses pembelajarannya. Inipula yang mengakibatkan pendidikan diniyah di madrasah diniyah kurang diminati calon siswa.

Kedua, perlu pengiriman buku-buku pelajaran standar madrasah diniyah untuk wilayah-wilayah yang belum mempunyai kurikulum sendiri dan di bawah standar nasional. Jikalau madrasah diniyah yang berada di pondok pesantren telah mempunyai standar kompetensi lulusan, namun dalam madrasah diniyah di tengah masyarakat, standar kelulusan dan juga buku-buku yang dipergunakan sangat terbatas. Sehingga, tidak jarang madrasah diniyah yang ada hanya seperti pengajian biasa yang mengajarkan baca tulis AlQuran saja.

Ketiga, penyelenggaraan pengawasan, pembinaan dan pendampingan bagi masing-masing madrasah diniyah per region yang tersebar di berbagai wilayah yang meliputi manajemen, pembelajaran dan lain sebagainya. Hal ini dimaksudkan untuk mengontrol perjalanan madrasah diniyah menuju madrasah yang bermutu dan berdaya saing serta berdaya guna bagi masyarakat. Para pengelola mengeluhkan bahwa keberadaan mereka selama ini kurang begitu diperhatikan. Dengan pola pendampingan per region seperti itu diharapkan mutu madrasah diniyah bisa ditingkatkan. Untuk itu, membangun kemitraan (partnership) dengan lembaga akademik lokal seperti perguruan tinggi agama untuk melakukan pendampingan secara terus menerus dan berkelanjutan.

Keempat, perlu dilakukan pemetaan ulang secara komprehensif dan teliti. Sehingga pengklasifikasian masing-masing madrasah diniyah sesuai dengan kenyataannya. Selain tidak sesuai dengan katagori yang ditentukan, masih banyak pula madrasah diniyah yang tidak tercantum dalam data EMIS.

Kelima, membangun kerjasama dengan pemerintah-pemerintah lokal baik tingkat provinsi maupun kabupaten. Hal ini terkait 
dengan pengalokasian anggaran pendidikan.

Beberapa wilayah sangat memperhatikan keberadaan madrasah diniyah. Di wilayah lain, madrasah diniyah tidak diperhatikan sama sekali dan dibiarkan hidup mandiri. Kerjasama dengan pemerintah lokal ini diharapkan minimal bisa membantu dalam hal pendanaan dan pemenuhan sarana prasarana serta kegiatan pembelajaran.

\section{Kontribusi Ilmiah}

Penelitian ini menemukan bahwa kajian dan penelitian tentang madrasah diniyah di Indonesia tidak banyak dilakukan peneliti dibandingkan dengan penelitian tentang madrasah seperti MI, MTs dan MA. Penelitian ini berupaya menggagas model pengelolaan madrasah diniyah yang ideal di era desentralisasi pendidikan dengan terlebih dahulu menganalisis peluang dan tantangan madrasah diniyah di era otonomi daerah.

\section{Kesimpulan}

Berdasarkan data dan analisis sebelumnya, maka ditarik kesimpulan sebagai berikut:

1. Terdapat peluang dalam pengembangan madrasah diniyah di Palopo karena banyak Taman Pendidikan Al-Qur'an (TPA) yang dapat dikembangkan menjadi madrasah diniyah (MD) yang lebih baik. Peluang lainnya adalah penetapan dimensi religi oleh pemerintah Kota Palopo sebagai arah pembangunan di Palopo sehingga eksistensi madrasah diniyah diharapkan memberikan kontribusi dalam perwujudan generasi muda yang agamis.

2. Tantangan yang dihadapi dalam perwujudan madrasah diniyah yang ideal di Kota Palopo dapat diidentifikasi sebagai berikut: pertama, sarana dan prasana yang kurang memadai. Kedua, tidak ada tokoh penggerak. Ketiga, dukungan masyarakat yang belum maksimal. Keempat, belum ada perhatian yang serius dari Pemrintah Kota. Kelima: masyarakat sudah merasa cukup dengan adanya Taman Pendidikan al-Qur'an (TPA). 


\section{Daftar Pustaka}

Al-Ainain, Ali Khalil Abu. 1980. Falsafah al-Tarbiyah al-Islamiyah, fi al-Quran al-Karim. Beirut: Dar a;-Fikr al-Araby.

Al-Munawwar, Said Aqil Husin. 2003. Aktualisasi Nilai-Nilai Qur'ani dalam Sistem Pendidikan Nasional Jakarta: Ciputat.

Azra, Azyumardy, 2005. Uraian Kata Pengantar dalam, Armai Arief, Reformulasi Pendidikan Islam. Jakarta, CRSD Press

—_- 1999. Pendidikan Islam Tradisi dan Modernisasi Menuju Milenium Baru. Jakarta: Logos.

Daulay. Haidar Putra. 2004. Pendidikan Islam dalam Sistem Pendidikan Nasional di Indonesia. Jakarta: Prenada Media.

Linrung, Tamsil. 1995. ICMI Beberapa Catatan Kritis Jakarta: Amanah Putra Nusantara.

Maksum, 1999. Madrasah: Sejarah dan Perkembangannya. Jakarta: Logos.

Mas'ud, Abdurrahman. 2004. Antologi Studi Agama dan Pendidikan. Semarang: Aneka Ilmu.

Nata, Abuddin. 2001. Paradigma Pendidikan Islam. Jakarta: Grasindo, 2001.

Nizar, Syamsul. Dasar-dasar Pemikiran Pendidikan Islam. Jakarta: Gaya Media Pratama.

PP Nomor 55 tahun 2007 tentang Pendidikan Agama dan Pendidikan Keagamaan

Riyadi, A. A. Riyadi, 2006. Politik Pendidikan: Menggugat Birokrasi Pendidikan Nasional. Yogyakarta: al-Ruzz.

Shihab, M. Quraish, 1992. Membumikan Al-Quran Fungsi dan Peran Wabyu dalam Kebidupan Masyarakat, Bandung: Mizan.

Surahim dan Usman Abu Bakar, 2005. Fungsi Ganda Lembaga Pendidikan Islam: Respon Kreatif terhadap Undang-Undang SISDIKNAS. Yogyakarta, Safiria Insani Pres

Undang-Undang Nomor 20 tahun 2003 tentang Sistem Pendidikan Nasional

\section{Makalah dan Sumber dari Internet}

Kaswad Sartono, 2008. Model Pembinaan Lembaga Pendidikan 
Diniyah dalam Kerangka Kebijakan Departemen Agama di Era Otonomi Daerah, Makalah disampaikan dalam Workshop Nasional Penyelenggaraan Madrasah Diniyah di Era Otonomi Daerah, oleh Balitbang Depag RI-STAIN Palopo, tanggal 27 Mei 2008 di Palopo

Anis Masykhur, Pencarian Identitas Pendidikan Diniyah di Indonesia, ttp://www.pondokpesantren.net/,

Agus, Maimun, Penyelanggaraan Madrasah diniyah Takmiliyah, http://tarbiyah.uin-malang.ac.id/Penelitian-2-penyelenggaraan-madrasah-diniyah-takmiliyah.html

Rosdiana, Respon Masyarakat Terhadap Madrasah Diniyah di Kota Palu, http://isjd.pdii.lipi.go.id/admin/jurnal/171111626_08541221.pdf

www.wikipedia.com/kotapalopo,

www.kotapalopo.go.id 